\title{
DE VEGHE ÎN TURPITUDINEA NEDEMNULUI. PROLEGOMENE ALE POSIBILEI INVOCĂRI
}

\begin{tabular}{lr}
\hline DOI: & $10.24193 / S U B B i u r .65(2020) .4 .13$ \\
Data publicării online: & 16.03 .2021 \\
\hline
\end{tabular}

\section{Codrin MACOVEI*}

Rezumat: Prezentul articol analizează un aspect particular al invocării nedemnități succesorale. Includem în sfera persoanelor care ar avea capacitate procesuală activă într-o acţiune în constatarea/declararea nedemnităţii pe: comoştenitorii legali sau testamentari (ale căror drepturi succesorale ar fi fost restrânse de venirea nedemnului la moştenire); moştenitorii legali subsecvenţi (pe care prezenţa nedemnului i-ar fi înlăturat de la moştenire); donatarii sau legatarii (ale căror liberalităţi ar fi putut fi reduse în cazul în care ar fi adus atingere cotei de rezervă succesorală a nedemnului); creditorii comoștenitorilor legali, ai moştenitorilor legali subsecvenţi, ai donatarilor sau legatarilor (exercitarea acţiunii oblice este permisă, nefiind vorba de un drept exclusiv personal); nedemnul însuși. Totuși, în privința nedemului există unele dileme. Până la a desluși un regim diferit al invocării în funcție de tipul nedemnității, de drept sau judiciare trebuie să răspundem la problema fundamentală a interesului său. S-ar putea aplica în privința sa principiul nemo auditur turpitudinem allegans? Înainte de afla un răspuns definitiv la această întrebare, prezentul articol își propune să determine care este natura juridică a acestei instituții și istoria sa.

Cuvinte cheie: nedemnitate succesorală, capacitate procesuală activă, nemo auditur turpitudinem allegans.

* Cadru didactic, Facultatea de Drept, Universitatea „Alexandru Ioan Cuza” din Iași, mcodrin@uaic.ro. 


\title{
THE CATCHER IN THE UNWORTHY HEIR'S TURPITUDE. PROLEGOMENA OF THE POSSIBLE INVOCATION
}

\begin{abstract}
This article examines a particular aspect of invoking succession unworthiness. Regarding the sphere of persons who would have active procedural capacity in an action to ascertain/stating the indignity, we include in this category: legal or testamentary co-heirs (whose inheritance rights would have been restricted by the coming of the unworthy to inherit); subsequent legal heirs (whom the presence of the unworthy would have removed from the inheritance); donees or legatees (whose liberalities could have been reduced if they had infringed the succession reserve quota of the unworthy); the creditors of the legal co-heirs, of the subsequent legal heirs, of the donees or legatees (the exercise of the oblique action is allowed, not being an exclusive personal right); the unworthy heir. However, there are some dilemmas regarding unworthy heir. Until we can discern a different regime of invocation depending on the type of indignity, legal or judicial, we must answer the fundamental question of its interest. Could the principle nemo auditur turpitudinem allegans be applied in this case? Before finding a definitive answer to this question, this article aims to determine the legal nature of this institution and its history.

Keywords: succession unworthiness, active procedural capacity, nemo auditur turpitudinem allegans.
\end{abstract}




\section{Cuprins}

I. Introducere. Valoarea unei expresii latine 479

II. Nedemnitatea succesorală: de la constatare și declarare la invocare 481

III. Repere diacronice ale evoluției regulii Nemo auditur propriam turpitudinem allegans

IV. Concluzii privind oportunitatea aplicării regulii Nemo auditur propriam turpitudinem allegans în materia nedemnității succesorale

I. Introducere. Valoarea unei expresii latine

Câteodată, utilizarea unui adagiu, brocard sau maxime latine pare să nu fie cea mai inspirată idee pe care doctrina juridică s-ar putea sprijini. În dovedire, s-a susţinut că această formă de respect pentru trecut ar fi periculoasă din mai multe considerente' ${ }^{1}$ Mai întâi, dacă un brocard traduce o regulă juridică aflată în vigoare, cutumiară, jurisprudențială sau doctrinală, atunci formula latină nu adaugă nimic forței regulii; dimpotrivă, ar putea face sensul mai greu înțeles. Mai apoi, dacă brocardul conține o regulă dispărută, situația este și mai contestabilă întrucât, în această situație, simpla invocare atrage consecința regretabilă a incertitudinii soluțiilor de care dispune știința dreptului. Dacă aceste considerente ar fi adevărate, atunci ar trebui să veghem cu grijă pentru a evita impunerea unui adagiu, oricât de respectabil fi prin vechimea sa, în măsura în care s-a demonstrat deja că nu ar mai putea primi vreun rol util. Prezenta lucrare ar dori să examineze actualitatea aplicării

${ }^{1}$ A se vedea, în acest sens, J. Bonnecase, Supplément au Traité théorique et pratique de droit civil de Baudry-Lacantinerie, Recueil Sirey, Paris, 1926, p. 776. Pentru demonstrația a priori a greșitei concepții tocmai expuse, a se vedea V.M. Ciucă, Lecții de drept privat comparat, $O$ introducere în hermeneutica organică a dreptului privat comparat, vol. 1, Ed. Fundației Axis, Iași, 2003, passim. 
adagiului Nemo auditur propriam turpitudinem allegans ${ }^{2}$ (în continuare evocat prin Nemo auditur) în materia nedemnității succesorale. În acest sens, plecăm de la constatarea domnului profesor Fr. Deak, aplicabilă reglementării nedemnității din Codul civil 1864:

„Cât privește invocarea de către nedemn a propriei sale nedemnități, împărtăş̧im soluția potrivit căreia nu poate primi aplicare principiul nemo auditur propriam turpitudinem allegans și deci este admisibilă invocarea nedemnității de către nedemn deoarece aceasta operează de drept, nedemnul referindu-se doar la faptul consumat al îndepărtării sale de la moștenire prin efectul legii”3

Ppentru a determina în ce măsură cele afirmate îşi păstrează actualitatea şi în ceea ce privește reglementarea nedemnităţii succesorale din Codul civil 2009.

${ }^{2}$ H. Roland, L. Boyer, indică în lucrarea Adages du droit français, 4ème éd., Litec, Paris 1999, p.483 că adagiul Nemo auditur este destinat să susțină morala publică, nu în sala de judecată, ci în societate; acesta urmărește același scop ca și Codul civil care sancționează imoralitatea cu nulitatea; este întotdeauna o problemă de prevenire a încheierii unor acorduri imorale, prevenire care pot fi obținută la fel ca printr-o anulare care interzice orice executare și printrun refuz de acțiune care face executarea inatacabilă. Alți autori plasează astăzi adagiul în cadrul unei existențe mai curând istorice: ,în secolul al XIX-lea, s-a considerat că scopul său era de a proteja demnitatea sistemului judiciar, la care s-a replicat corect că recursul la justiție este un drept și că magistrații aud alte imoralități în zilele noastre; susținătorii regulii preferă să spună că rolul său este să se opună unui drept care rezultă dintr-o situație imorală” - M. Dagot, La simulation en droit privé, LGDJ, Paris, 1967, nr. 288, p. 281. Adagiul este cunoscut în țările europene sub mai multe forme cum ar fi Nemo creditur propriam turpitudinem allegans sau Nemo allegans seram turpitudinem est audiendum. Common-law cunoaște un adagiu similar: „who comes into equity must come with clean hands".

3 Fr. Deak, Tratat de drept succesoral, ed. a II-a actualizată și completată, Ed. Universul Juridic, București, 2002, p. 72; a se observa și nota 4 subsol pentru opinii concurente, divergente și exemple jurisprudențiale. 
II. Nedemnitatea succesorală: de la constatare și declarare la invocare

Nedemnitatea succesorală este reglementată de Legea nr. 287/2009 privind Codul civil, Cartea a IV-a - „Despre moștenire și liberalități”, capitolul II - „Condiții generale de a moșteni”, art. 958-961. Dispozițiile acestora reglementează cazurile de nedemnitate de drept, cazurile de nedemnitate judiciară, efectele nedemnităţii și înlăturarea efectelor acesteia.

Cazurile de nedemnitate sunt prevăzute de art. 958 și 959 Cod civil, aceste prevederi aplicându-se „numai faptelor săvârşite după intrarea în vigoare a Codului civil”, potrivit art. 93 din Legea nr. 71/2011 pentru punerea în aplicare a Codului civil.

Noul Cod civil reglementează nedemnitatea de drept, în art. 958 Cod civil, şi nedemnitatea judiciară, în art. 959 Cod civil.

Termenul „nedemn” provine din francezul indigne, însemnând „nevrednicie”. Spre deosebire de alte instituții juridice pentru care avem definiţii legale, a căzut în sarcina doctrinei să definească nedemnitatea succesorală. Orientându-ne atenția spre această problematică, putem observa că în doctrină s-au concretizat trei opinii cu privire la natura juridică a nedemnității succesorale.

Pe de o parte, unii autori consideră nedemnitatea ca fiind o sancţiune civilă, motivat de faptul că hotărârea prin care instanța de judecată constată nedemnitatea produce efecte retroactive, având un caracter declarativ, nu constitutiv de drepturi, cum ar fi fost necesar în cazul aplicării unei veritabile 
pedepse civile4. În plus, se argumentează că excluderea nedemnului de la moștenire se produce în temeiul legii ${ }^{5}$, nu al simplei voințe a celui care lasă moștenirea. Astfel, distincția dintre nedemnitatea de drept şi cea judiciară nu ar fi și sub aspectul naturii juridice, ci doar al modului în care sunt aplicate dispozițiile legale, respectiv ex lege sau prin intervenția instanței judecătorești, la solicitarea oricărui succesibil. Drept urmare, defunctul ar putea interveni numai în sensul de a înlătura efectele nedemnității ${ }^{6}$.

Precizăm că aceste efecte pot fi înlăturate doar prin iertarea expresă a nedemnului, prin testament sau act autentic notarial, iertarea tacită nefiind permisă. Voința în acest sens trebuie să provină de la de cujus şi să fie exteriorizată după momentul săvârșirii faptelor, în cunoștință de cauză, motiv pentru care trebuie să conțină suficiente date pentru identificarea autorului şi a faptei care atrage nedemnitatea.

Pe de altă parte, a fost expus şi punctul de vedere potrivit căruia nedemnitatea succesorală este o pedeapsă civilă7. Sub imperiul Codului civil din 1864, se aprecia că această natură juridică derivă din rațiuni de moralitate

4 Fr. Deak, Tratat de drept succesoral, ed. a II-a actualizată și completată, Ed. Universul Juridic, București, 2002, p. 72, Fr. Deak, R. Popescu, Tratat de drept succesoral, vol. I, Ed. Universul Juridic, București, 2013, p. 96 și nota de subsol nr. 3, I. Urs, Drept civil. Succesiuni: curs universitar, Ed. Universul Juridic, București, 2017 p. 28, L. Stănciulescu, Moştenirea. Doctrină şi jurisprudenţă, Ed. Hamangiu, Bucureşti, 2017, p. 73, D. Negrilă, Moştenirea în Noul cod civil. Studii teoretice şi practice, Ed. Universul Juridic, Bucureşti, 2015, p. 137, G. Boroi, L. Stănciulescu, „Instituții de drept civil în reglementarea noului Cod civil”, Editura Hamangiu, București, 2012, p. 526, I. Nicolae, Devoluțiunea legală și testamentară a moştenirii, Ed. Hamangiu, București, 2016, p. 61.

5 V. Stoica, L. Dragu, Moştenirea legală în Noul cod civil, Ed. Universul Juridic, Bucureşti, 2012, p. 54; D. Negrilă, op.cit., p. 99; M. M. Soreaţă, Noutăţi legislative în material succesiunilor, Ed. Hamangiu, Bucureşti. 2013, p. 25; D.C. Florescu, Dreptul succesoral în noul Cod civil, ediția a II-a, revăzută și adăugită, Editura Universul Juridic, București, 2012, p. 31.

${ }^{6}$ L. Stănciulescu, op.cit., p. 73.

7 J. Kocsis, P. Vasilescu, Drept civil. Succesiuni, Ed. Hamangiu, Bucureşti, 2016, p. 17. 
publică, considerându-se inadmisibil ca o persoană care se face vinovată de fapte de o asemenea gravitate față de o alta să vină la moștenirea acesteia din urmă. Mai mult, se aduce și argumentul caracterului personal al acestei instituții de drept, acest caracter cântărind chiar și mai greu în noua reglementare, sens în care descendenții nedemnului nu mai suportă efectele nedemnității, ci pot veni la moștenirea lui de cujus prin reprezentare succesorală.

$\mathrm{Au}$ calitate procesuală pasivă într-o acțiune în constatarea nedemnităţii: moștenitorul nedemn; succesorii nedemnului ce stăpânesc prin retransmitere bunurile succesorale dobândite de nedemn (este ipoteza în care nedemnul care a intrat în posesia bunurilor moștenirii decedează înainte de constatarea nedemnităţii, iar acestea se transmit, în cadrul propriului său patrimoniu succesoral, la proprii săi moștenitori).

Într-o a treia opinie, natura juridică diferă după cum nedemnitatea este de drept sau judiciară ${ }^{8}$. În primul caz, vorbim despre o sancțiune civilă, efectele nedemnității producându-se automat, ope legis. În al doilea caz, natura juridică este de pedeapsă civilă, întrucât este indispensabilă pronunțarea unei hotărâri judecătorești, fiind necesar chiar ca instanța să constate existența anumitor fapte și să dispună înlăturarea nedemnului de la respectiva moştenire. Și efectele acestei hotărâri declarative retroactivează până la momentul deschiderii succesiunii, considerându-se că cel declarat nedemn nu a avut niciodată calitatea de moștenitor.

Aceste variabile ar putea avea anumite efecte în ceea ce privește determinarea modului de funcționare a instituției invocării nedemnității.

8 C. Macovei, M.C. Dobrilă, Cartea a IV-a. Despre moştenire și liberalitățî, în FI.A. Baias, E. Chelaru, R. Constantinovici, I. Macovei (coord.), Noul Cod civil. Comentariu pe articole, Editura C.H. Beck, București, 2012, pp. 1079. 
Astfel, întrucât nedemnitatea prevăzută de art. 958 operează de drept, nu este necesară și o altă hotărâre judecătorească care să constate intervenirea nedemnităţii. Totuşi, există posibilitatea ivirii unui litigiu în legătură cu îndeplinirea condițiilor cerute de lege pentru intervenirea unei asemenea sancțiuni civile. Într-o atare situaţie, instanța, ca singur organ competent, este chemată să se pronunțe cu privire la îndeplinirea acestor cerințe și, dacă este cazul, să constate nedemnitatea ce a operat ope legis din momentul deschiderii succesiunii. În ceea ce privește momentul în care ar putea fi promovată o astfel de acțiune, acesta este situat în mod obligatoriu după deschiderea succesiunii. Întrucât $o$ astfel de acțiune are ca finalitate îndepărtarea nedemnului de la moștenirea celui față de care s-a făcut vinovat de faptul de nedemnitate, acțiunea în constatarea nedemnității poate fi primită numai dacă nedemnul are vocație succesorală legală concretă la moștenirea în cauză, în caz contrar acțiunea urmând a fi respinsă ca lipsită de interes. În ceea ce privește sfera persoanelor care ar avea calitate procesuală activă într-o acțiune în constatarea nedemnității, includem în această categorie: comoștenitorii legali sau testamentari (ale căror drepturi succesorale ar fi fost restrânse de venirea nedemnului la moștenire); moștenitorii legali subsecvenți (pe care prezența nedemnului i-ar fi înlăturat de la moștenire); donatarii sau legatarii (ale căror liberalități ar fi putut fi reduse în cazul în care ar fi adus atingere cotei de rezervă succesorală a nedemnului); creditorii comoștenitorilor legali, ai moştenitorilor legali subsecvenți, ai donatarilor sau legatarilor. Pe de alte parte, nedemnitatea judiciară este condiționată de intervenirea unei hotărâri a instanței de judecată civile care să pronunțe îndeplinirea elementelor constitutive a unuia dintre cele trei cazuri analizate. În ceea ce privește persoanele care au calitate procesuală activă, facem trimitere la precizările deja făcute în cazul 
nedemnității de drept, art. 958 C. civ., cu o diferență: suntem de acord cu precizarea făcută de domnul profesor Romeo Popescu9 - în această situație declararea nedemnității ține de decizia succesibililor lui de cujus, iar admiterea exercitării acțiunii pe cale oblică ar încălca, într-adevăr, libertatea deciziei lor, care este una evident personală.

În situația în care declararea judiciară a nedemnității reprezintă singura piedică în constatarea vacanței succesorale, alin. (6) al art. 959 C. civ. prevede, în mod expres, calitatea procesuală activă a comunei, orașului sau, după caz, municipiului în a cărui rază teritorială se aflau bunurile lui de cuius la data deschiderii moștenirii, în condiții asemănătoare cu a celorlalți moștenitori; condiția inexistenței altor succesibili la care se face referire trebuie înțeleasă în sens strict juridic, ca făcând referire la absența unor moștenitori cu vocație utilă epuizării întregii succesiuni. Interesul promovării acțiunii care rezidă în concretizarea sau lărgirea emolumentului vocației succesorale îndreptățește calificarea actului procesual ca act de acceptare tacită a moșteniri, indiferent de soluția pronunțată.

Întrebarea care se ridică este aceea referitoare la posibilitatea invocării propriei turpitudini de către nedemn. Poate acesta să o facă atât în cazul nedemnităţii de drept, cât și a nedemnității judiciare? Ar putea cineva cere respingerea acestei pretenții prin invocarea Nemo auditur? Pentru a putea contura un răspuns, ar trebui să conturăm mai exact conținutul acestei reguli.

9 Fr. Deak, R. Popescu, Tratat de drept succesoral, ed. a IV-a, actualizată și completată, vol. I, Moștenirea legală, Ed. Universul Juridic, București, 2013, p. 129, nota 2 subsol.

\section{5}


III. Repere diacronice ale evoluției regulii Nemo auditur propriam turpitudinem allegans

Chestiunea supraviețuirii în dreptul nostru pozitiv a regulii Nemo auditur propriam turpitudinem allegans nu a născut controvers $\mathrm{e}^{10}$. Cu totul alta este însă situația în dreptul francez, unde în orizontul adoptării Codului civil napoleonean (1804) s-au format două tabere, de susținători și opozanți ai aplicării acestei excepții de impuritate, infamie, ignominie, ticăloșie, răutate, necinste. Până astăzi, nici chiar în cadrul vreuneia dintre aceste tabere nu pare a exista unanimitate în determinarea fundamentului, aplicării şi nici măcar al sensului exact al acestei reguli și, cu atât mai mult, nu există o partidă câştigătoare. Este cert doar faptul că jurisprudența franceză a ultimelor două secole s-a depărtat în mod constat de la aplicarea sa ${ }^{11}$, preferând în schimb legalismul întemeierii soluțiilor pe dispozițiile exprese ale Codului civil 1804. Considerăm că luminarea cauzelor acestor dispute ${ }^{12}$ ar putea fi de ajutor în înțelegerea limitelor aplicării preceptului în dreptul nostru succesoral, mai exact în domeniul nedemnităţii succesorale.

\footnotetext{
${ }^{10}$ A se vede în acest sens și P. Drăghici, Aplicații ale răspunderii civile in cazul regulii „nemo auditur propriam turpitudinem alegans”, Analele Universităţii "Constantin Brâncuşi” din Târgu Jiu, Seria Științe Juridice, Nr. 1/2010, p. 33 și urm.

${ }^{11} \mathrm{G}$. Lamassoure, La règle nemo auditur propriam turpitudinem allegans exclusivement considérée dans son application au Droit civil français actuel, Thèse pour le doctorat, Bordeaux, 1936, pp. 61-95.

12 Studiul acestui adagiu a făcut în Franța obiectul a numeroase teze de doctorat în special în prima jumătate a secolului al XX-lea; în plus față de teza mai sus citată mai menționăm: P. Guiraudet, Essai sur la maxime Nemo auditur propriam turpitudinem allegans, Paris, 1913, G.J. Tzarano, Etude sur la règle: „Nemo auditur propriam turpitudinem allegans”, LGDJ, Paris, 1924, M. Savey-Casard, Le refus d'action pour cause d'indignité, Thèse pour doctorat, Lyon, 1930, Ph. le Tourneau, La règle „nemo auditur...”, coll. Bibliothèque de droit privé, LGDJ, Paris, 1970. Efervescența a fost exportată și în Elveția: R. Secrétan, La règle „Nemo auditur propriam turpitudinem allegans” en droit suisse, S.E.A.M., Geneva, 1952.
} 
Mai întâi, am dori să subliniem că trecutul îndelungat al acestei maxime ar putea fi înșelător: Roma a cunoscut, fără îndoială, excepția invocării propriei turpitudini ${ }^{13}$, la fel ca dreptul medieval ${ }^{14}$. Cu toate acestea, expresia exactă Nemo auditur propriam turpitudinem allegans, pare să fi fost necunoscută romanilor ${ }^{15}$, ea devenind uzuală mult mai târziu, în evul mediu, când a fost compusă de la zero. În dreptul roman, celui care efectuase o datio în temeiul unui fapt contrar moralei i se acorda o condictio - ob turpem causa - fără a mai observa dacă accipiens își executase sau nu obligațiile. Tradens primea astfel posibilitatea restituirii plății sale, iar accipiens era astfel sancționat pentru încălcarea moralei. În cazul în care ambele părți se făceau vinovate de încălcarea regulilor morale, condictio $o b$ turpem causa era refuzată acelui trades care era apreciat imoral: „Ubi autem et dantis et accipins turpitudo versatur: non posse repeti dicimus; si et dantis et accipientis turpis causa sit, possessorum potiorum esse; et ideo repetitionem cessare tametsi ex stipulatione solutum est" ${ }^{16}$. Acestea par a fi precedentele maximei Nemo auditur, reguli ce par a apăra posesia şi în acelaşi timp conțin voința de a îl pedepsi pe vinovat. Între cele două deziderate, imperativul de a nu favoriza un vinovat era privit ca prioritar ${ }^{17}$.

Abia începând cu secolul al XII-lea refuzul autorizării unei acțiuni pentru cauză de imoralitate se justifică prin invocarea regulii Nemo auditur. De această dată caracterul moral și religios al acesteia este evident, dar ideea

\footnotetext{
13 De exemplu, în aplicarea concretă: „in pari causa turpitudinis cessat repetitio, in pari causa possessoris melior conditio habeatur".

14 M. Savey-Casard, Le refus d'action pour cause d'indignité, Thèse pour doctorat, Lyon, 1930, p. 19-70.

15 Ibidem, p. 20.

16 Digeste, $12-5-8$.

17 M. Savey-Casard, op.cit., pp. 69-70.
} 
de protecţie acordată posesiei nu este totalmente pierdută, aceasta fiind recuperată odată cu Renașterea ${ }^{18}$.

Astfel, pentru J. Domat (1625-1696), ,convențiile ilicite nu sunt numai nule ci şi pedepsibile în măsura în care încalcă scopurile și spiritul legilor"19; marele jurist francez face următoarele două distincții, urmând soluțiile dreptului roman:

1. „dacă convenția este ilicită doar pentru cel care primește și nu pentru cel care dă, ca de exemplu, depozitarul care solicită bani pentru restituirea bunului depozitat gratuit, sau hoțul pentru restituirea a ceea ce a furat, cel care a achitat banii are dreptul la restituire, chiar dacă cel care i-a primit a executat convenția”"20;

2. „dacă actul este ilicit atât din partea celui care dă, cât şi din parte celui care primește, cel care a dat va pierde ce a folosit într-o manieră greşită şi nu va avea nicio acțiune pentru recuperare. Nici cel care a primit nu va putea reține acest profit injust; dacă însă acesta ar fi executat deja angajamentul ilicit pentru care a primit plata, el va fi obligat la restituirea a ceea ce a executat și ținut să răspundă cu celelalte pedepse pe care le va fi meritat" 21.

J. Domat face aplicarea Nemo auditur, dar nu în mod mecanic. Atunci când ambii contractanți se fac vinovați de încălcarea moralei, marele jurist

\footnotetext{
18 G. Lamassoure, op.cit., p. 9.

19 J. Domat, Effets des conventions illicites et malhonnêtes, Livre I, Tome XVIII, Sect. IV, nr. 3 .

20 Ibidem, nr. 5 .

${ }^{21}$ Idem, Répétition de l' Indû, Livre II, Tome VII, Sect. II, nr. 4.
} 
francez se plasează prin cei care resping ipoteza restituirii, propunând cu titlu de noutate $o$ altă soluție și anume confiscarea prestaţiilor, astfel încât nici una dintre părți să nu mai poate păstra vreun profit. Soluția sa nu a fost însușită nici de jurisprudență, în lipsa unui text de lege expres şi nici de doctrină, întrucât confiscarea ar conduce la dezinteresarea sesizării justiției de către părțile actului ilicit ${ }^{22}$.

În schimb, alţi autori iluștri ai timpului, cum ar fi, R.J. Pothier (16991772) fac aplicarea netă a principiului Nemo auditur ${ }^{23}$ după modelul anterior menționat al Digestelor.

Raportându-ne la momentul adoptării Codului civil francez, prin Legea din 21 martie 1804 se prevedea că odată cu intrarea în vigoare a acestuia sunt abrogate orice alte reguli concurente de drept, fie ele legale sau cutumiare ${ }^{24}$. În măsura în care Codul nu conținea nici o trimitere la regula Nemo auditur se ridică întrebarea legitimă în ce măsură aceasta putea continua să existe şi după acest moment. Totuşi, primii comentatori ai textelor napoleoniene nu au fost preocupați de supraviețuirea maximei și nu atât mai puțin de compatibilitatea sa cu noile reglementări. Iată cum, jurisconsulții Școlii exegezei precum P.-A. Merlin de Douai25 (1754-1838), C.É. Delvincourt (1762-1831), J.-B.-V. Proudhon (1758-1838), J. de Maleville

\footnotetext{
22 G. Lamassoure, op.cit., p. 11.

23 R. J. Pothier, Traité des Obligations, Paris, 1864, nr. 45, nr. 193.

24 Art. 7 din Legea din 21 martie 1804 (Loi sur la réunion des lois civiles en un seul corps, sous le titre de Code civil des Français) prevedea următoarele: „compter du jour où ces lois sont exécutoires, les lois romaines, les ordonnances, les coutumes générales ou locales, les statuts, les règlements, cessent d'avoir force de loi générale ou particulière dans les matières qui sont l'objet desdites lois composant le présent code” - Bull. des Lois, 3e S., B. 354, nº 3677.

25 Acest autor, în volumul Recueil alphabétique des questions de droit qui se présentent le plus fréquemment dans les tribunaux, quatrième édition, revue, corrigée et considérablement augmantée, Tome II, Paris, 1827, p. 215, aplică direct regulile Digestelor pentru a decide soarta acțiunii în restituire. Codul civil este ignorat complet.
} 
(1741-1824), Ch.-B.-M. Toullier26 (1752-1835), A. Duranton ${ }^{27}$ (1783-1866) șiau însuşit regula întrucât au găsit-o utilizată de predecesorii lor (Domat, Pothier, Berbeyrac) ${ }^{28}$. În plus, ei nu identificaseră o abrogare expresă a acesteia, iar soluția menținerii li se părea naturală prin influența ataşamentului propriu față de Ancien Droit, iar prin acesta față de dreptul $\operatorname{roman}^{29}$.

Ulterior, supraviețuirea Nemo auditur a fost mult mai profund contestată de autorii Şcolii Exegezei dreptului civil. Motivele sunt, de altfel, destul de evidente. Este suficient să menționăm printre trăsăturile caracteristice ale acestei şcoli cultul pentru textul de lege, interpretarea textului de lege care favorizează aplicarea intenției legiuitorului, importanța acordată statului și argumentelor autoritățiii3o. Iată cum, un jurist bine-

${ }^{26}$ Acest autor, în lucrarea Le Droit civil français suivant l' ordre du Code, Quatrième édition, Paris, 1824, Tome VI, Ch. II, nr. 126, susține următoarele: „dacă cineva nu merită să păstreze recompensa crimei sale, lașul corupător merită și mai puțin să recupereze ce a dat [...], trebuie deci să ne abținem de la regula generală și să dăm preferință posesorului [...], aceasta fiind regula Dreptului roman”, citând regula de condict. ob turpem causam și autori precum Barbeyrac și Pufendorf (ultimul cu operele Le Droit de la nature et des gens, respectiv Les Devoirs de l'homme et du citoyen).

27 Acest autor în lucrarea Cours de Droit civil français suivant le Cod civil, Paris, 1830, Tome X, p. 391, reține că „dacă ambele părți au încălcat regulile licitului sau bunelor moravuri, nu va exista acțiune pentru a fi solicitată executarea oblogației, iar dacă a fost deja executată, nu se va restitui ceea ce a fost plătit. Cu atât mai mult, dacă cel care a făcut promisiunea era singurul aflat într-o situație asemănătoare, nu va putea cere restituirea a ceea ar fi plătit. Aceasta este, conform lui Ulpian, cazul în care un cetățean a dat bani unei curtezane (fie în executarea unei promisiuni, fie fără promisiune prealabilă)”. Și în acest caz, suntem în prezența reafirmării regulii dreptului roman care se opune restituirii în situația turpitudinii cocontractanților.

28 J. Bonnecase, La pensée juridique française de 1804 á l' heure présente, Ses variations et ses traits essentiels, Ed. Delmas, Bordeaux, 1933, Tome II, p. 289.

29 Ibidem.

$3^{\circ 0}$ A se vedea și J. Bonnecase, L' Ecole de l' Exégèse en Droit civil. Les traits distinctifs de sa doctrine et ses méthodes d' après les professions de foi de ses plus illustres représentants, $\mathrm{E}$. de Boccard, éditeur, Paris, 1924. 
cunoscut precum F. Laurent (1810-1887) afirmă că dacă legiuitorul nu a menționat o regulă bine cunoscută dreptului francez înainte de adoptarea Codului civil napoleon, acest aspect echivalează cu interzicerea sa ${ }^{31}$. Totuşi, chiar și în cadrul acestei școli, atât de ataşată de astfel de argumente, regula Nemo auditur şi-a găsit apărători. Îl putem da ca exemplu pe M. L. Larombière (1813-1893) ${ }^{32}$ care susținea că tăcerea asurzitoarea Codului în privința receptării regulii Nemo auditur este motivată de admiterea implicită a regulii care îl inspira pe Pothier, iar dacă autorii codului ar fi dorit eliminarea normei ar fi trebuit să o facă în mod expres. Altfel, conchide autorul, în fața tăcerii Codului civil triumfă autoritatea lui Pothier, susţinătorul maximei medievale33.

Probabil observând paradoxul interpretării complet opuse a absenței oricărei referiri a Codului napoleon la regula Nemo auditur de către autorii vremii sale, un alt autor propune o soluție salvatoare pentru dăinuirea acesteia. Pentru J. Bozérian (1825-1893) fundamentul regulii studiate trebuie ancorat în morală 34 . Cele două, dreptul și morala nu au domenii distincte de acțiune. Regula morală este întotdeauna prezentă, încoronând regula de drept, iar dacă nevoia o cere o poate înlătura pe aceasta din urmă. Iată un exemplu: cel care a achitat o obligație nulă întrucât este motivată de o cauză ilicită nu ar trebui să primească nimic înapoi din punctul de vedere al dreptului; dar, moralmente, el era ținut de conștiința sa proprie să execute o

${ }^{31}$ F. Laurent, Principes de droit civil français, Livre XVI, Paris, 1875, nr. 164.

$3^{2}$ M. L. Larombière, Théorie et pratique des obligations, ou Commentaire des titres III et IV, livre III du Code civil, art. 1101 à 1386, Tome V, Paris, 1857, Commentaire á l' article 1133, nr. 9 .

33 Ibidem.

34 J. Bozérian, Revue practique de Droit française, jurisprudence, doctrine, législation, Paris, 1958, Tome V, p. 15 și urm. 
obligație pe care a consimțit-o și care rămâne valabilă ca o obligație morală. Astfel, solvens nu ar trebui să se derobeze moral, prin acțiunea în repetițiune, de la obligațiile sale morale. Din punct de vedere moral, omul care încercă să folosească în interes propriu lipsa de respect a cuvântului dat, nu trebuie ascultat de justiție35. Acest autor insistă că nu doar morala ar fi înfrântă prin neaplicarea principiului Nemo auditur ci şi ordinea publică ar avea de suferit dacă s-ar putea reveni asupra unor convenții încheiate și executate cu mult timp în urmă.

Argumentele Şcolii Exegezei, în sensul susținerii regulii Nemo auditur, cunosc și alte nuanțări. Într-o încercare de juridizare a aplicării, autori precum profesorul E. Dubois (1813-1893) apreciază că efectele Nemo auditur sunt perfect adaptate pentru combaterea convențiilor ilicite: nulitatea va fi eficace dacă îl abandonăm pe solvens bunei-dispoziții a cocontractantului său, refuzându-i acțiunea în restituire ${ }^{36}$. Deși soluția sa lasă loc impreciziei (comportamentul cocontractantului nu poate fi prezis), teoria lui Dubois poate fi apreciată ca inovativă pentru că menționează și posibilitatea existenței de excepții de la aplicarea regulii de drept în situațiile în care interesul public ar cere-o şi astfel deschide orizontul apărării supraviețuirii maximei prin auto-adaptarea la exigențele jurisprudenței. Exemplu dat de autor, în acest sens, priveşte restituirea sumelor de bani achitate peste prețurile fixe stabilite de stat 37 .

\section{Ibidem.}

36 E. Dubois, Notă sub Decizia Curți de Casație franceze din data de 15.12.1873 privind turpitudinea comună a părților unui contract de cesiune a unei case de toleranță, în Recueil général des lois et des arrêts: en matière civile, criminelle, commerciale et de droit public, fondator J.-B. Sirey, Paris, 1874 p. 241, nr. 1.

37 Ibidem, p. 242. 
Credem că sinteza opiniilor favorabile anterior prezentate este realizată de către E. Dramard (1831-1906), judecător la Curtea de Apel Limoges, prin teoretizarea Nemo auditur ca regulă aptă să slujească unui dublu rol. Pe de o parte, regula poate împiedica executarea unei convenții ilicite, atunci când aceasta este clamată în justiție, iar pe de altă parte descurajează afișarea publică a înțelegerilor imorale cu scopul de obține restituirea unei prestații executate în considerarea acestora ${ }^{38}$. În ambele ipoteze, interesul public este cel care dictează: Nemo auditur interzice proba actului ilicit sau imoral ori de câte ori cel care își întemeiază pretențiile pe proba uneia dintre aceste circumstanțe a consimțit la actul în discuție. Astfel, convențiile pe care Dreptul și Morala le condamnă nu vor mai fi expuse interesului și atenției publice, societatea fiind asanată chiar de existența lor, iar participanți sancționați. Invers, contractantului care nu a consimțit nici la încălcarea legii și nici la nesocotirea onoarei, îi va putea fi admisă acțiunea în restituire. Practic, prin aceste susţineri autorul împacă atât opiniile divergente în privința câmpului de aplicare al regulii (convenții ilicite v. convenții imorale), cât şi justificarea naturii instituției (regulă juridică v. regulă morală), integrând toate viziunile predecesorilor săi într-o teorie coerentă. Aceeaşi viziune, deşi într-o formă simplificată, este împărtăşită şi de autori mai bine cunoscuți în țara noastră, cum ar fi Aubry și Rau39.

În pofida tuturor acestor demonstrații, detractorii supraviețuirii Nemo auditur după momentul adoptării Codului civil napoleonian nu au fost mai puțini la număr. L-am menționat deja pe juristul belgian F. Laurent. Lui i se

$3^{8}$ E. Dramard, Traité des effets de complaisance en droit civil et commercial et en droit pénal, Ed. Durand, Paris, 1880, p. 57 și urm.

39 C. Aubry, C. Rau, Cours de droit civil français d'après la méthode de Zacharie, Quatrième édition, Tome quatrième, Paris, Imprimerie et Librairie Générale de Jurisprudence, 1871, p. 739. 
alătură juriști precum M. Duvergier (1792-1877), care susține că intenția Codului civil a fost de a desființa toate convențiile contrare bunelor moravuri şi ordinii publice ${ }^{40}$. Astfel, dacă am permite executarea parțială a unor astfel de convenții, dacă le-am recalifica ca putând conține o obligație naturală, dacă am încerca aplicarea regulii in pari causa turpitudinis melior est causa possidentis, atunci noua ordine instituită de Codul civil ar fi literă moartă. Mai mult, dacă am înțelege să fondăm Nemo auditur pe existența unei obligații morale (a conștiinței) nu am înțelege că soluția Codului civil este aceea a desființării fără remuşcări, iar dacă am da curs consecințelor unei posesii trecătoare am arunca dreptul în brațele hazardului. Toate aceste consecințe sunt foarte grave pentru M. Duvergier, care îşi întemeiază astfel antipatia față de nemo auditur, calificând-o ca empirică, ilogică și suspectăă1

Autoritatea Nemo auditur este însă atacată sub toate aspecte de către J. Ch. Fl. Demolombe (1804-1887). Acest universitar francez începe tratarea regulii prin interogația retorică care vizează găsirea locului unde ar fi ea scrisă ${ }^{2}$. Neidentificându-l, autorul afirmă că, pe cale de consecință, nu este posibil ca doar autoritatea „pur istorică” a Nemo auditur să fundamenteze hotărâri jurisprudențiale care să se raporteze la acesta ca la o normă legală irefragabilă. Dar demersul lui J. Ch. Fl. Demolombe nu se rezumă doar la

$4^{\circ}$ M. Duvergier, Les sommes payées en exécution de traités secrets faits par les titulaires d'offices sont sujettes à répétition, în Revue Etrangère et Française de Législation, de Jurisprudence et d' Economie Politique, Tome VII, Paris, 1840, p. 568 și urm.

${ }^{41}$ Ibidem.

42 J. Ch. Fl. Demolombe, Cours de Code Napoléon, Traité des contrats ou des obligations conventionnelles en générale vol. XXIV, Tome Deuxième, Imprimerie Générale de Ch. Lahure, Paris, 1869, p. 363 și urm. 
respingerea formală a recunoaşterii Nemo auditur. Este concepută o argumentație amplă în patru puncte ${ }^{43}$, după cum urmează:

1. Nemo auditur este contrazisă chiar de regulile exprese ale Codului civil napoleonean; acesta ar prioritiza aplicarea principiului qoud nullum est nullum producit effectum, care în aplicare nu poate menține niciun efect al contractului ilicit așa cum o face adagiul istoric;

2. Nemo auditur este contrazisă de principiile științei juridice; astfel, nulla poena, sine lege se opune în mod cert existenței unei sancțiuni fără un text formal și precis, fiindcă este evident că aplicarea Nemo auditur conduce la lipsirea reclamantului de o acţiune; mai mult, sancțiunea nulităţii pentru cauză ilicită este absolută, de ordine publică și poate fi invocată de oricine, pe când excepția Nemo auditur ar putea fi utilizată doar de către pârât în condiții mult mai restrictive, iar această situație ar încălca nivelul de apărare a intereselor publice instituit prin Codul civil;

3. argumentele de ordin moral și cele care țin de ordinea publică pot fi invocate şi împotriva aplicării Nemo auditur; în primul rând, aducerea la lumină a convențiilor imorale va avea un caracter preventiv, descurajând încheierea unor convenții imorale; tot din punct de vedere moral, lăsarea obiectului prestației executate în mâinile celui care a primit executarea și care nu va fi obligat la restituire prin excepția Nemo auditur ar putea fi apreciat de public ca fiind o încurajare, o primă;

43 Ibidem. 
dimpotrivă, părțile, indiferent dacă sunt ambele de reacredință, sau doar una dintre ele, ar trebui să ştie cu certitudine că nimic nu poate să fie reținut cu titlu de profit personal dintro activitate care este contrară ordinii publice;

4. aplicarea Nemo auditur dă naştere unor dificultăți şi contradicții care îi divizează chiar pe susținătorii săi; aici, deja, cititorul nostru știe la ce anume exact face referire J. Ch. Fl. Demolombe și nu credem că ar mai trebui să insistăm.

Aceasta este, practic, platforma program la care au aderat mulți autori după J. Ch. Fl. Demolombe pentru a respinge autoritatea Nemo auditur şi pentru a cere ca jurisprudența să nu o aplice. De multe ori s-a întâmplat ca meritele lui J. Ch. Fl. Demolombe în construcţia celei mai fluente ideologii anti Nemo auditur să nu fie recunoscute, ideile sale fiind deseori preluate în viitor ca noi...44.

Cele expuse anterior credem că ar creiona destul de fidel contextul apariției, limitele aplicării și ale contestării regulii Nemo auditur. Autorii care au urmat s-au raliat, fie taberei apărătorilor, fie taberei opozanților. Desigur, există nuanțe, exemple şi argumente personale, dar trecerea tuturor în revistă ar depăşi scopul prezentei lucrări. În acest sens, am dori să punem punct acestei prezentări diacronice chiar cu concluziile unui important jurist francez din prima jumătate a secolului al XX-lea, L.M.A.G. Ripert (1880-1958). Profesorul francez conchide că supraviețuirea maximei Nemo auditur în dreptul francez reprezintă un exemplu al precumpănirii regulilor morale asupra regulilor juridice ${ }^{45}$. Maxima a suportat atacuri ample, doctrina îi este

44 G. Lamassoure, op.cit., p. 37.

45 L.M.A.G. Ripert, La règle morale dans les obligations civiles, LGDJ, Paris, 1925, nr. 104110, 130, 198. 
în majoritate ostilă, iar jurisprudența i-a respins în numeroase ipoteze aplicarea ${ }^{46} . \mathrm{Cu}$ toate acestea, dacă domeniul de aplicare al regulii s-a restrâns în mod constant după intrarea în vigoare a Codului civil napoleonian, caracterul său moralizator s-a accentuat, iar în condițiile în care o regulă juridică ar încălca în mod evident o regulă morală îi revine jurisprudenței sarcina de a asigura aplicarea cu prioritate a ultimei 47.

Aceste susțineri ale eminentului jurist francez nu au fost, până astăzi, contrazise. Cel puțin Curtea de casație franceză pare să îi fi dat întrutotul dreptate, întrucât printr-o decizie de speță din anul 2004 a casat parțial o hotărâre a unei Curții de Apel, pentru aplicarea falsă a principiului „potrivit căruia nimeni nu poate profita de propria lui turpitudine" 48 . Se apreciază că prin această decizie, regula „nemo auditur” a fost ridicată la rangul de „principiu general al dreptului” de către Curtea de Casație ${ }^{49}$.

${ }^{46}$ Ibidem.

47 Ibidem.

48 A.-Fr. Eyraud, Note sous Civ. 1ère, 22 juin 2004, Juris-Classeur Périodique (Semaine Juridique), 2005, II, 10006, p. 85.

49 Ibidem. Totuși, concluziile anterioare privitoare la respingerea aplicării maximei de către instanțe rămân valabile. Iată câteva exemple: Tribunalul din Nanterre a respins regula Nemo auditur în temeiul unei interpretări stricte: „... acest adagiu interzice să ne bazăm pe natura imorală a unei stipulări, dar nu și pe natura sa ilicită, așa cum este cazul în acest caz” - doctrina clasică ar fi încântată: legea nu se confundă cu morala - T.G.I. Nanterre, 8 noiembrie 1995, D. 1996, Jur. p. 242, nota Chauchard; CA Paris, 4 decembrie 1990, D. Sirey 1991, I.R. p. 29. 1394 Soc., 16 ianuarie 2002, „A revenit Curții (din Paris) să ia în considerare acest element”, prin urmare aplicarea nemo auditur este la dispoziția instanței: adagiul nu are o valoare mai mare decât legea: „O [...] dispoziție legislativă precisă și imperativă nu poate fi derogată în virtutea unui simplu adagiu, cum ar fi nemo auditur propriam turpitudinem allegans, adagiu admis în materie de răspundere contractuală”; alte exemple de respingere a aplicării regulii: Trib. Civil Grenoble, 11 juillet 1923, Trib civ. Seine, 7 janvier 1948, citate de J. Vidal, Essai d'une théorie générale de la fraude en droit français. Le principe " fraus omnia corrumpit », Thèse, Dalloz, Paris, 1957, p. 196-197. 
IV. $\quad$ Concluzii privind oportunitatea aplicării regulii Nemo auditur propriam turpitudinem allegans în materia nedemnității succesorale

După cum am putut observa în cadrul secțiunii anterioare, câmpul de predilecție al aplicării istorice a adagiului Nemo auditur este limitat la materia contractelor, în special la soluționarea consecințelor unui act imoral sau ilicit. Acestei observații i s-ar adăuga dezamăgirea produsă de lipsa caracterului roman propriu-zis al adagiului, deși credem că aceasta din urmă poate fi uşor depăşită prin considerarea parcursului temporal îndelungat şi valoros. Dar chiar şi aşa, aparent, Nemo auditur nu se regăseşte în poziția optimă pentru a organiza respingerea invocării turpitudinii de către nedemn.

În primul rând, nedemnul nu cere nici restituirea unei prestaţii executate în cadrul unui act desființat ca urmare a incidenței nedemnității şi nici păstrarea unui alt avantaj patrimonial. Constatarea sau declararea sa ca nedemn ar profita în primul rând moștenitorilor care îndeplinesc condițiile cerute de lege pentru a putea moșteni. Ar putea exista beneficii și pentru nedemn ca urmare a invocării de către el a propriei turpitudini? Situația cea mai des vehiculată de doctrină ca exemplu pentru existența unui interes legitim al nedemnului de a-şi invoca propria turpitudine ar fi situația în care creditorii succesiunii îl urmăresc pe acesta pentru plata datoriilor. În acest caz, ar câștiga ceva nedemnul? Desigur, el evită blocarea unor eventuale valori patrimoniale proprii, dar orice câștig al său (care, mai exact, ar consta în evitarea unor pierderi...) nu se face pe seama moștenirii sau a moștenitorilor şi sigur nu pe seama creditorilor. Mai mult, câş̧tigul este al circuitului civil care astfel este ferit de incertitudinea sorții viitoare a actelor încheiate de nedemn cu acești creditori. Desigur, putem imagina și alte situații care l-ar 
avantaja direct sau indirect pe nedemn. Ar evita oare astfel nedemnul raportarea unei donații pe care ar fi obligat să o raporteze chiar și în cazul renunțării sale la moștenire, conform art. 1.147 alin (2) Cod civil? Ar reuşi astfel nedemnul să își avantajeze copiii care vor veni la moștenire prin reprezentare, în condițiile în care știind că dacă ar moșteni chiar nedemnul bunurile dobândite acestea ar face obiectul executării silite din partea creditorilor?

Mai apoi, invocarea nedemnității chiar de către nedemn nu face decât să servească scopului instituţiei succesorale în discuţie. Practic, s-ar acorda prioritate nedemnității, ca instituție ce previne consecințele inechitabile derivând din venirea nedemnului la moștenirea celui față de care se face vinovat de comiterea unor fapte grave sau a cărui ultimă voință a nesocotit-o, în detrimentul ideii de a anihila beneficiile injuste pe care le-ar putea obține persoana în cauză pe calea invocării propriei nedemnităţi.

În acest moment, ar fi util să revenim asupra naturii juridice a nedemnității. În cazul nedemnității de drept, natura juridică a sancțiunii ne indică că aceasta intervine automat. Prin invocarea nedemnităţii chiar de către nedemn nu se realizează decât o asumare a efectelor. Lipsa acestei invocări ar conduce, cel mult, la o amânare a aplicării efectelor, dar niciodată la o remediere a situației de drept în favoarea nedemnului. Singurul care ar fi putut face acest lucru ar fi fost de cujus, prin iertare. În cazul nedemnității judiciare, natura juridică a pedepsei indică implicarea activă a celor car ar urmări aplicarea acesteia. Cum pentru existența nedemnității judiciare trebuie să existe măcar un succesibil care să sesizeze instanța cu o cerere în declararea nedemnității, putem să apreciem că în această situație iertarea celui vinovat de faptele nedemnității judiciare ar putea veni, nu numai din partea lui de cujus, ci, în mod indirect, chiar din partea celor interesați în 
promovarea unei astfel de acțiuni. În această accepțiune, invocarea propriei nedemnității de către cel vinovat, ar ocoli intenția legiuitorului de a delega moralizarea relațiilor succesorale la îndemâna succesibililor. Mai mult decât atât, împotriva invocării de către nedemn a propriei turpitudini pot fi invocate şi alte argumente, de natură formală. Pornind de la art. 959 alin. (2), orice „succesibil” care justifică un interes poate solicita instanței de judecată să declare nedemnitatea. Prin termenul „succesibil” înțelegem persoana care îndeplinește toate condițiile pentru a putea veni la moștenire, dar care nu şia manifestat încă opțiunea succesorală, în sensul acceptării sau renunțării. În mod evident, persoana în cauză nu s-ar încadra în noțiunea de succesibil, deoarece nedemnitatea apare ca o condiție generală negativă a dreptului de a moșteni. Deși la momentul introducerii acțiunii în declararea nedemnității persoana îndeplinește încă toate condițiile prevăzute de lege, hotărârea declarativă a instanței ar produce efecte retroactive, desființând titlul de moștenitor încă de la data deschiderii moştenirii. Pentru a complica şi mai mult situația, persoana care introduce acțiunea în declararea nedemnității este considerată drept acceptant tacit al moşteniri. Astfel, reglementarea ar fi defectuoasă dacă i s-ar permite succesibilului să accepte moștenirea, ca ulterior să îşi invoce propria nedemnitate pentru a fi decăzut din dreptul de a moșteni, în condițiile în care acceptarea este un act irevocabil. Tot în acest sens, respingem în totalitate ideea că eventualul conflict moral în care se găsește persoana vinovată de o faptă a nedemnității ar putea fi rezolvat, nu prin invocarea nedemnității, ci prin renunțarea la moștenire, pentru un motiv evident: deținerea dreptului de opțiune succesorală și exercitarea lui valabilă presupune îndeplinirea condițiilor prevăzute de lege pentru a putea moșteni (art. 1.100), deci inclusiv lipsa nedemnității. 
Paradoxal, condiția actuală a regulii Nemo auditur ne poate îngădui mai uşor adoptarea unei soluții. Evoluția Nemo auditur cuprinde moralizarea sa și procesul transformării sale într-un principiu de drept. Tocmai acestă autoritate inspiră rezolvarea cu prioritate a conflictului moral în care se găsește cel vinovat de comiterea unei fapte a nedemnității. A-i permite să invoce propria turpitudine, însemnă împlinirea exactă a tipului de răspundere imaginat de legiuitor pentru pedepsirea anumitor fapte succesoral culpabile, chiar dacă asta ar însemna admiterea unei excepții de la limitele formale ale reglementării din noul Cod civil. Iar, în final, această soluție ne-ar aduce, credem, mai aproape de concepția romanilor asupra fundamentelor dreptului şi de sensibilitatea lor atotcuprinzătoare prin exceptio exceptionis causa. 